\title{
Implementing Promising Practices To Prepare Quality Teacher Educators
}

\author{
Ruben Gentry, Jackson State University, USA
}

\begin{abstract}
The United States does more than just talk; it invests a lot of money in public education. While students are the major focus of concern, teachers are a mainstay in the enterprise. In 2002, the U.S. invested $\$ 192$ billion in teacher pay and benefits. More than $50 \%$ of all dollars allocated by the government for education is paid in salaries for teachers, yet there is little research to guide decisions as whom to hire, retain, and promote (Rice, 2003). However, the general consensus is that under good teachers, students get a good education, and under poor teachers, students get a poor education. The difference between the two makes a world of difference. The U. S. cannot afford to trust its most valuable asset - students - to the tutelage of poor teachers. Doing so would be to run the risk of needlessly suffering from medical conditions, financial woes, and a quality of life not befitting a highly advanced nation.

This manuscript provides a functional framework for the student and faculty, a review of related literature, and a detailed description of an individual effort at implementing promising practices to prepare quality teacher educators. The expectation is that information and preliminary findings that are provided will, in some way, further thinking and effort at producing effective teachers to staff our schools.
\end{abstract}

Keywords: Professor Competencies; Faculty-Student Engagement; Teacher Education; Teaching Strategies; Student Motivation

\section{INTRODUCTION}

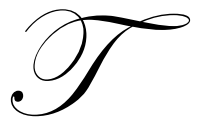

he value of education in the U. S. was brought to light by the country's founding fathers. Thomas Jefferson perhaps best described the importance of education in his renowned statement, "If a nation expects to be ignorant and free, in a state of civilization, it expects what never was and never will be" (QuoteDB, 2005). To achieve the civilization and quality of life that was envisioned, education has constantly been an item on the U. S.'s agenda. School reform and educational improvement are at the heart of what U. S. citizens live and breathe.

What do teachers do that makes their presence so important in the educational system? They shape minds and change lives. Teachers develop or shape the curriculum, deliver the instruction, assess student progress, and place a stamp of approval on the finished product - school graduate. Good teachers are invaluable and irreplaceable.

\section{PURPOSE}

Careful thought was given to the very bare elements needed to prepare educational personnel, in light of existing economical and societal conditions. The specific quest was to ascertain the most crucial combination of sources to produce quality teachers and chart a course of action for its attainment. Evidence pointed toward the student educator and the college professor; they are viewed as most influential in the preparation of quality teachers. 


\section{THE STUDENT/PROFESSOR FRAMEWORK}

If the student educator and college professor are the key to ensuring a quality teacher product, what individual and cooperative roles must the two perform to achieve a quality product? Attention was focused on the question. To put the framework in perspective, general evidence suggested that it would take a determined or groovy student and an inspiring professor to produce a quality teacher. The individual and combined efforts of the two needed for this accomplishment are provided.

\section{The Determined Student}

Why do people want to teach and when is the decision made? One of the main reasons given for wanting to teach is to make a difference in the lives of children. A student's desire to become a teacher might go back a long way or it could be a recent discovery. He or she may have had a good grade teacher worth emulating; teaching may run in the family; it may be simply a love for children; it may be attractive because it is viewed as the profession that serves as the foundation for all professions; and so on (Selwyn, 2007).

When interest in teaching is first realized, excitement is often associated with it. The person looks forward to entering the profession. When they arrive at the university, they are ready to work for change, to make the world a better place, and to do good work; their passion and energy are electric (Selwyn, 2007). Unfortunately, along the schooling path, it is not uncommon for many prospective teachers to lose some of their zeal for teaching, even to the point that many would-be-teachers become disenchanted and seek other professions, or those that continue the pursuit give less than that $110 \%$ effort needed for adequate teacher preparation. Why does this happen? It may be that "the trees interfere with seeing the forest." Disheartening occurrences may include having teachers that do not inspire them to teach, curricula that do not seem purposeful, or an overall college experience that does not seem very relevant.

Now, a very fundamental "comeback" question may be raised - "If a person has or ever had a burning desire to teach, can that flame be made to glow again?" Very likely, especially if an inspiring professor appears on the scene. The student may experience what Stella did in the movie, "Stella Got Her Groove Back." Stella was a single mother in her 40's with a pre-teen son and was a power-packed professional, but she was no longer in possession of her "groove." However, she longed to get it back. It happened that Stella took a trip to Jamaica and enjoyed the sun, breeze, weather, sand, and, of course, the company of a very young man. Stella got back her groove. She said, "It's a rhythm, a stride, a feeling of being on cruise control, the knowledge of being in control;" and "When you recapture that groove, you feel good and things start falling into place" (McMillan, 1996).

The charge here is to enable teacher candidates to rekindle their determination or get their groove back, or simply, to become determined. CARE (Commitment, Achievement, Responsiveness, and Enthusiasm), which is discussed in detail later, may serve as a guide for students who desire to reclaim or form self-determination to become an effective teacher.

\section{The Inspiring Professor}

Words, including facilitator, guide, etc., have been suggested to describe the desired professor. The description chosen for this manuscript is inspiring. Professors who inspire do more than simply lecture, make assignments, supervise activities, and test. Inspiring professors also make teaching relevant, authentic, and lively. Ultimately, university students' outlook and attitudes can be positively impacted by an inspiring professor (Gebhard, 2006).

The professor is one of the most important components in the teaching and learning process. As such, no two semesters should be the same, for what is learned in one semester should lead to change and improvement for the next semester. Particular attributes of the effective or inspiring professor are that he/she:

- $\quad$ Models the kind of understanding and wisdom that students should seek to develop

- $\quad$ Motivates high academic engagement and competence 
- $\quad$ Fosters a positive, reinforcing, and cooperative environment

- Makes connections across curricula, using skills they are learning elsewhere (Faculty teaching/learning institute at Saginaw Valley State University, n.d.; The Effective Teacher, n.d.)

Sometimes the inspiring professor may be found encouraging candidates to put forth their best efforts in class activities, while other times he or she may be found celebrating the successes that the candidates have achieved. It was stated in one case (The University of Nebraska at Lincoln: Academy of Distinguished Teachers, n.d.) that their research and teaching missions are thoughtfully harmonized, though it requires even more care with respect to undergraduate education. The report further indicated that skills essential to research are central to undergraduate learning. Evidence-based inquiry, consideration of alternative views, critical thinking, appreciation of the impermanence of established knowledge, tolerance of complexity, clear definitions of concepts, and the examination of assumptions are attributes of thoughtful scholarship for students at every level of higher education.

\section{The Student And The Professor}

In the act of teaching and learning, the candidates bring a lot to the table; but just among each other, the learning will not be in full perspective. The professor can deliver a lot of knowledge, but if the candidates are not in a receptive mode, the information will fall on deaf ears. It takes determined or groovy students and an inspiring professor to produce quality teachers.

\section{THE QUALIFIED TEACHER VERSUS THE QUALITY TEACHER}

From review of related literature, it was observed that the concept "good" teacher was used extensively, but its meaning varied tremendously among its users. Educators and policymakers have attempted to clarify the meaning of qualified teacher through a standards-based approach. If a person meets the established standards, he/she is certified as a "highly qualified" teacher. The No Child Left Behind (NCLB) Act defines highly qualified, mostly in terms of content (Selwyn, 2007). Its requirements for meeting the definition of highly qualified are: 1) having earned at least a bachelor's degree, 2) demonstrates content knowledge in each core content area he/she teaches, and 3) not having any waivers of requirement for full state certification (South Carolina Department of Education, n.d.).

Universities and colleges have gone to great length to identify the "right" set of competencies that will enable a person to become a qualified teacher. Unfortunately, these products face tremendous challenges, among which are: 1) too many students underachieve, 2) the student drop-out rate is extremely high, 3) teacher morale is low and the rate of turnover is high, and 4) lack of public confidence in the schools. Further, research findings are mixed as to whether teacher academic abilities translate to achievement in the classroom (Selwyn, 2007). In essence, qualified teachers are not necessarily high "quality" teachers.

Pioneers of the standards movement have undoubtedly brought teacher preparation a long way. Nothing can substitute for prerequisite competencies that a person must have to be successful in the classroom. The person must have the knowledge, teaching skills, and practical experiences to get off to a good start in teaching. In simple terms, qualified teachers are the cake, but quality teachers are cake with icing on it.

Chief among the distinguishing characteristics of quality teachers is enthusiasm. Influential teachers feel very passionately about their subjects and are able to generate a contagious energy about them (Gebhard, 2006).

Evidence of a quality teacher in the making can also be noted. Successful college students do their homework, attend every class, and participate in teamwork (Fox Valley Technical College - Knowledge that works, n.d.). The examination of a candidate's performance while matriculating in college and the observation of his/her behaviors and characteristics reveal a lot about the quality of teacher that is in the making. In this manuscript, key points of investigation and development are subsumed in the acronym, CARE (Commitment, Achievement, Responsiveness, and Enthusiasm). It is important for universities to prepare teacher candidates who CARE. 
Behaviors and competencies for preparation of quality teachers have also been delineated. They include the ability to:

- $\quad$ Transform knowledge into effective student understanding

- $\quad$ Demonstrate positive regard for all students

- $\quad$ Establish high, but not unreasonable, standards

- Work to enhance students' own motivation and capacity to learn

- Use light touches and humor to create a sense of community

- $\quad$ Seek continual improvements in present and future performance (Faculty teaching/learning institute at Saginaw Valley State University, n.d.)

Rice (2003) stated that teacher quality is the most important school-related factor influencing student achievement. The author gives five categories to reflect teacher quality: 1) teacher experience, 2) teacher preparation programs and degrees, 3) teacher certification, 4) teacher coursework, and 5) teachers' own test scores. The National Survey of Student Engagement (NSSE) frames the quality of college education into five benchmark categories: 1) level of academic challenge, 2) active and collaborative learning, 3) level of student/faculty interaction, 4) enriching educational practices, and 5) supportive campus environment (Wild, 2005). The effectiveness of a particular program was perceived, in part, from the answer that students gave to the question, "Would they choose that university if they had it to do all over again?"

From another perspective, quality teaching may be approached by viewing it as consisting of two conceptually separate parts - good teaching and effective teaching. Andrew, Cobb, and Giampietro (2005) addressed good teaching and effective teaching in terms of teacher attribute and broad interactions. They indicated that good teaching is a complex interaction of a wide range of teacher characteristics, abilities, dispositions, knowledge of subject fields, experience, and pedagogical knowledge. Effective teaching is achieved when these factors appropriately interact with particular school cultures, sets of educational goals, and children. Berliner (2005) stated that good teaching occurs when the standards of the field are upheld. It is considered normative and made up of at least three components: 1) logical acts of teaching (defining, demonstrating, modeling, explaining, correcting, etc.), 2) the psychological acts of teaching (caring, motivating, encouraging, rewarding, punishing, planning, evaluating, etc.), and 3) moral acts of teaching (showing honesty, courage, tolerance, compassion, respect, fairness, etc.). The author goes on to state that effective teaching is about reaching achievement goals; it is about students learning what they are supposed to in a particular class. However, the highly qualified taker of tests about teaching should not be confused with a highly qualified classroom teacher. To assess what is really wanted would require highly discerning observers who spend their time watching teachers teach (Berliner, 2005).

\section{A PARTICULAR ENDEAVOR TO PRODUCE QUALITY TEACHERS}

If teachers are so important in the education of our students, how are they best prepared? As the title of this manuscript states, it requires a determined student and an inspiring professor. One particular university attempted to attain this lofty goal. Information is provided on the program description, specific purpose, procedures, and obtained results.

\section{Program Description}

The Historically Black University at which this investigation took place has a long tradition of preparing personnel for the teaching profession. It is accredited by the Southern Association of Colleges and Schools (SACS) and the National Council for the Accreditation of Teacher Education (NCATE). Its graduates have gone on to staff various positions in schools and agencies throughout the state and the nation. Formal and informal survey data have shown that many are successful in their chosen positions. Included among the university's graduates are former U.S. Secretary of Education, Rod Paige (Rod Paige, n.d.), and legendary football player, the late Walter Payton (Taylor, 2002).

Recent observations revealed that the program's teacher candidates were experiencing both internal and external issues. Regardless to major, many of the students appeared short on zeal and enthusiasm for the teaching 
profession. Some felt a lack of support from the faculty in guiding them through the program. One student exclaimed, "they (the faculty) don't care about us." Some teacher education majors were passing coursework but struggling with Praxis tests, even to a point that a number of them were giving up on the tests and pursuing nonteaching majors. On the other side of the desk, some faculty didn't seem to think very highly of the students. They exclaimed that their class attendance was erratic, their writing skills were poor, and that they weren't truly concerned about their education (Personal communications, 2007-08).

\section{Problem}

To determine what it would take to make students CARE, or become more determined in a university environment and have a professor who could facilitate the cause, was the goal for the investigation. It appeared that, at a minimum, students needed to attend class, successfully complete assignments, participate in practica, and to feel good about the college experience. Thus, one professor headed an initiative to bring about such a change in the performance of his students.

\section{Procedures}

The University was doing all of the standard things that accredited teacher education programs are expected to do. Programs of study were properly approved, competent faculty were assigned to teach, course syllabi were developed, field experiences were incorporated, grading criteria were provided, and a class attendance policy was distributed. All of the standards for excellence were in place, yet there was not a lot of excitement about the challenge at hand. It came to mind that the situation was similar to what occurred in the movie "Stella Got Her Groove Back." The students just didn't seem to have their groove. As it took a man to help Stella get her groove back (McMillan, 1996), it would take a professor to help students get their groove back; not just any professor, but an inspiring one.

The courses in which the procedures were applied were from the department of special education. Students enrolled in the courses had majors in various teacher education programs. The instructor was a tenured professor who professed an abiding love for both the subject and the students.

Through an exploratory process over time, it appeared that the teaching objective should be to help candidates become more determined about their profession and to enable them to CARE (demonstrate Commitment, Achievement, Responsiveness, and Enthusiasm in the training program). How do students demonstrate CARE? These are the criteria and required performances:

- $\quad$ First, students must come to class. To accomplish this goal, the professor literally expressed how their presence was valued and needed, gave frequent class assessments, and often connected subject content to matters with which they were familiar.

- $\quad$ Students needed to purchase, read, and use the textbook. To ensure that these things would happen, frequent reference was made to specific pages and illustrations and open-book tests were given for most chapters.

- $\quad$ Students needed to attempt, and successfully complete, all course assignments. To facilitate this quest, the professor would explain the course requirements and due dates for assignments on day 1, monitor all submissions, provide instant feedback and any needed individual advisement, and make mention in class of salient points included in their completed assignments.

- $\quad$ Students needed to put their learning into practice. To make the activity an experience to remember and a profitable one, the professor sought appropriate field-based placements and collaborated and interacted with the students on site.

- Last, but not least, the students needed to "feel" the overall experience of preparing to teach. To help enable this attainment, the professor aimed at raising the interpersonal skills bar, referred to them as teacher education "candidates", and emphasized that there was a special place awaiting each in a school setting to put into use all their learning and love for students (University files, 2007-08). 
CARE embodied the crucial domains for preparing teachers, but there were more specific procedures and strategies employed in the effort to prepare quality teachers, such as:

- $\quad$ Class started on day 1 and went the full scheduled period.

- Professor had students introduce themselves, give their major, where they were from, and specify something they liked. (The professor often knew someone from that city and asked the students if they knew the person or made another statement of common interest. He also made mental note of what the student liked and appropriately made reference to it at points throughout the course.)

- $\quad$ Professor gave the students a title that inspired respect, dignity, and great expectation. He let them know that they were no longer considered students; they were teacher education candidates.

- $\quad$ Professor learned and called each student by name; the one that they preferred. (It became an honorable name; e.g., "Candidate" Mary).

- Candidates were encouraged to be "their brother's keeper." (If one student was absent, inquire as to what was happening.)

- $\quad$ Professor emphasized that there were times for strict independent performance, but collaborative effort is the cornerstone for modern education.

- $\quad$ Professor had a variety of course assignments and solicited the students' best efforts on each.

- Professor gave immediate feedback and was quick to recognize, reward, and reinforce successful achievement.

- $\quad$ Professor made known that his success was measured by the candidates' success, even the so-called least of them.

- $\quad$ Professor saw each candidate as the "little engine that can" become a most excellent educator.

- $\quad$ Professor accentuated that college learning was dynamic and that at any given point in a lesson, any candidate could "score a touchdown" (as was said of the late Walter Payton anytime he got hand on the football).

- $\quad$ Professor and candidates celebrated gained performance in the classroom, across campus, everywhere! (never forgoing an opportunity to tell someone concerned how well the candidates were performing in the program)

\section{RESULTS}

The big question was, "Did this teacher preparation process facilitate the production of determined teachers who CARE?" Data were gathered and analyzed to determine the success of teacher candidates in each area of CARE:

Commitment - The determining variables were class attendance and possession of the textbook.

Achievement - The assessable measures were assignment submissions and final grade proficiency.

Responsiveness - The assessable factors were clinical experience/option and class presentation/research paper/option performance.

Enthusiasm - Data variables were provocative statements in oral/written reports and looks on their faces (pictures taken, etc.).

Data for the areas (CARE) were gathered throughout the duration of the particular course.

What happens when a determined or groovy student and an inspiring professor come together? You get a CARE teacher education candidate. As reflected in Table 1, the results for students in a SPED 311 - Survey of Exceptional Children and Youth in the Schools course taught during a summer session - were very impressive in several areas. For textbook possession and multi-media presentation completion, the rate of accomplishment for each was $100 \%$. Candidates also did well on all course requirements completion (99.4\%), class attendance (94.1\%), 
and clinical experience/option completion (93.3\%). A modest performance was registered for final grade proficiency $(84.8 \%)$.

Table 1: Performance of Undergraduate Students on Course Criteria

\begin{tabular}{llll}
\hline Criteria & & & \\
\hline Class attendance & No student x No class sessions & Total attendance & Attendance rate \\
& $15(18)=270$ & 254 & $94.1 \%$ \\
Textbook possession & No of students & No with book & Percent w book \\
& 15 & 14 & 100.0 \\
Clinical exp/op comp & No of students & No completing & Percent of students \\
& 15 & 14 & 93.3 \\
Multi-media completion & No of students & No completing & Percent of students \\
& 15 & 15 & 100.0 \\
All course require comp & No of stud x no required & Total no completed & Completion rate \\
& $15(12)=180$ & 179 & $99.4 \%$ \\
Final grade proficiency & No students x possible points & Grade points earned & Proficiency rate \\
& $15(1244)=18660$ & 15837 & $84.8 \%$ \\
Criteria average & & & Average percent \\
& & & $95.3 \%$ \\
\hline
\end{tabular}

Notes: (1) Students were not counted absent until they first attended class. (2) Excused absentees were not counted as absent.

Table 2 contains the results for SPED 500 - Survey of Exceptional Children and Youth course that was also taught during a summer session. The data were more impressive; however, this was a graduate course. For textbook possession, multi-media presentation, research, and all course requirements completion, the rate of accomplishment for each was $100 \%$. Candidates also did very well on class attendance $(96.9 \%)$. The average performance reached the low "A" range for final grade proficiency $(90.1 \%)$.

Table 2: Performance of Master's Level Students on Course Criteria

\begin{tabular}{llll}
\hline Criteria & & & \\
\hline Class attendance & No student x No class sessions & Total attendance & Attendance rate \\
& $13(15)=195$ & 189 & $96.9 \%$ \\
Textbook possession & No of students & No with book & Percent w book \\
& 13 & 13 & 100.0 \\
Multi-media completion & No of students & No completing & Percent of students \\
& 13 & 13 & 100.0 \\
Research & No of students & No completing & Percent of students \\
& 13 & 13 & $100.0 \%$ \\
All course require comp & No of stud x no required & Total no completed & Completion rate \\
& $13(11)=143$ & 143 & $100.0 \%$ \\
Final grade proficiency & No students x possible points & Grade points earned & Proficiency rate \\
& $13(1130)=14690$ & 13242 & $90.1 \%$ \\
Criteria average & & & Average percent \\
\end{tabular}

Notes: (1) Students were not counted absent until they first attended class. (2) Excused absentees were not counted as absent. (3) One student withdrew in week 2, so no data were included on her.

Other qualitative results that appeared evident were:

- $\quad$ Self-esteem was immensely enhanced.

- $\quad$ Students actually put forth extensive effort to achieve academically.

- $\quad$ Attendance became par for the course.

- $\quad$ Sociability, team work, and collegiality were displayed (Personal communication, 2007-08). 


\section{CONCLUSION AND IMPLICATIONS}

One thing upon which U. S. citizens can agree is that it is important for our children and youth to obtain a very good education, so much so that tremendous resources are allocated to achieve it. Another point of agreement is that teachers play a major role in the educational process. What presents a challenge is producing effective teachers to staff our schools.

To produce good teachers, teacher education programs are emphasizing the preparation of "qualified" personnel. However, it has been shown that qualified teachers are not necessarily quality teachers. There is no argument that all teachers should first be qualified; they should meet the standards established as essential competencies for entering the profession. But quality teachers are needed. The quality teacher is a qualified teacher who further exemplifies personal/affective development and the ability to interact effectively with various constituents in the learning environment.

In an endeavor to produce quality teachers, one university focused on two dimensions considered essential in the process - a determined or groovy student and an inspiring professor. First and foremost, a determined student must be a competent or potentially competent student. Second, the student must exemplify special affective qualities that are manifested both personally and interpersonally. The inspiring professor must first be knowledgeable of the discipline and one who can interact strategically and extensively with students in the learning process. He/she must be able to make learning alive and authentic in the classroom.

Education takes on new meaning and perspective when students get back the determination or groove that they first had when they envisioned teaching as a profession, and the professor helps by harmonizing facets of the learning experience to make for a meaningful and rewarding adventure. A professor will best know that he/she is on the road to producing quality teachers when the teacher education candidates CARE (demonstrate Commitment, Achievement, Responsiveness, and Enthusiasm). The results, as reported from two courses, indicated that the two working together gained ground in producing a more quality teacher (enhanced professional attributes) that schools so desperately need to educate our children - the U. S.'s most valuable resource.

\section{AUTHOR INFORMATION}

Ruben Gentry is professor of special education at Jackson State University (MS). He earned the Ed.D. degree from the University of Florida and did further study at Harvard and Cornell. His experience includes public school teacher, college professor, department chair, associate provost, and visiting coordinator of Academic Affairs at the Mississippi Institutions of Higher Learning Board Office. His scholarly work has addressed effective administration and teaching strategies. E-mail: ruben.gentry@jsums.edu.

\section{REFERENCES}

1. Andrew, M.D., Cobb, C.D., \& Giampietro, P.J. (2005). Verbal ability and teacher effectiveness. Journal of Teacher Education, 56(4), 343-354.

2. Berliner, D.C. (2005). The near impossibility of testing for teacher quality. Journal of Teacher Education, 56(3), 205-213.

3. Faculty teaching/learning institute at Saginaw Valley State University. (n.d.). Retrieved from http://www.svsu.edu/ dboehm/Qualities.html

4. $\quad$ Fox Valley Technical College - Knowledge that works. (n.d.). Retrieved from http://www.fvtc.edu/public/content.aspx?id=1659\&pid=4

5. Gebhard, S. (2006). The lost boys (and girls): Readers in Neverland. Journal of Teacher Education, 57(5), 454-463.

6. McMillan, T. (1996, December). "Stella" in South Africa: Still looking for her groove. Ebony, Retrieved from http://findarticles.com/p/articles/mi_m1077/is-v52/ai-18953522

7. QuoteDB. (2005). Retrieved from http://www.quotedb.com/quotes/3678

8. Rice, J. (2003). Teacher quality: Understanding the effectiveness of teacher attributes. Retrieved from http://www.epinet.org/content.cfm?id=1500 
9. $\quad$ Rod Paige, U.S. Secretary of Education - Biography. (n.d.). Retrieved from http://www2.ed.gov/news/staff/bios/paige.html

10. Selwyn, D. (2007). Highly qualified teachers: NCLB and teacher education. Journal of Teacher Education, 58(2), 124-137.

11. South Carolina Department of Education. (n.d.). Retrieved from http://www.scteachers.org/titleii/qualified.cfm

12. $\quad$ Student Planner. (2007-2008). Dayton, OH: Woodburn Press.

13. Taylor, R. (2002). Walter Payton, Bears RB, 1975-1987. Retrieved from http://www.bearshistory.com/lore/walterpayton.aspx

14. The Effective Teacher. (n.d.). Retrieved from http://cela.albany.edu

15. University of Nebraska at Lincoln: Academy of Distinguished Teachers. (n.d.). Retrieved from http://cehs.unl.edu/cansorge/academy/whitePaperPages/researchTeaching.html

16. Wild, R. (2005). What makes a good university? Could it be as simple as a ranking on a list? The Magazine of Marquette University, 24(2), 2. 
NOTES 